УДК $342.9 ; 342.6$

DOI https://doi.org/10.32837/yuv.v0i5.2244

\author{
А. Колісник, \\ доктор філософіі, \\ здобувач наукового ступеня доктора наук \\ кафедри адміністративного права та адміністративної діяльності \\ Національного юридичного університету імені Ярослава Мудрого
}

\title{
ПРАВОВИЙ СТАТУС, КОМПЕТЕНЦІЯ ФІСКАЛЬНИХ ТА РОЗВІДУВАЛЬНИХ ОРГАНІВ У СЕКТОРІ ЕКОНОМІЧНОЇ БЕЗПЕКИ ДЕРЖАВИ
}

Постановка проблеми. Стат тя 17 Конституції України передбачає, що захист суверенітету і територіальної цілісності України, забезпечення їі економічної та інформаційної безпеки $€$ найважливішими функціями держави, справою всього Українського народу. Стан економічної безпеки має важливе значення для розвитку багатьох галузей та $є$ своєрідним індикатором інвестиційної привабливості Української держави. 3 огляду на часто непрогнозоване посилення світової тенденції розповсюдження нових викликів економічним сферам держав, зокрема, застосування економічних засобів для досягнення політичних цілей країни, повинні зосередитися на управлінні економічними ризиками та наділяти відповідні вітчизняні інститути повноваженнями щодо виявляння та нейтралізації відповідних загроз. Забезпечення національних інтересів та створення економічного безпекового середовища держави багато в чому залежить не лише від наявності суб'єктів ї забезпечення, а й від їхньої злагодженої роботи на підставі чіткої нормативно-правової бази. На жаль, підхід українського законодавця до регламентації сфери економічної безпеки держави є дещо не системним, внаслідок чого як розвідувальні, так і фіскальні органи, несправедливо розглядаються дещо відокремленими від інших суб'єктів ii забезпечення. Саме тому дослідження правового статусу та компетенції даних органів $є$ просто необхідною умовою для внесення пропозицій щодо оптимізації їхньої діяльності, яка відіграє не останню роль у системі гарантування економічної безпеки держави загалом.

Метою та завданням роботи $€$ дослідження положень вітчизняних нормативно-правових актів для визначення правового статусу органів розвідки та фіскальних органів, а також систематизації їхніх повноважень у сфері економічної безпеки України.

Аналіз останніх досліджень і публікацій. На жаль, у загальнотеоретичних дослідженнях наукові праці, в яких з позицій науки адміністративного права досліджувались правовий статус і компетенція фіскальних та розвідувальних органів у секторі економічної безпеки держави, практично відсутні.

Виклад основного матеріалу. Визначення правового статусу і компетенції розвідувальних та фіскальних органів у сегменті захисту вітчизняної економіки доцільно розпочати 3 визначення поняття «економічна безпека». Основним нормативно-правовим актом у сфері національної безпеки в Україні є Закон України «Про національну безпеку України» від 21.06.2018 р. № 2469-VIII (далі Закон № 2469-VIII), положення якого хоч і передбачають, що державна полі- 
тика у сферах національної безпеки і оборони спрямовується й на забезпечення економічної безпеки, однак дефініції даному поняттю не надають. Більш спеціалізованим актом у досліджуваній нами сфері є Стратегія економічної безпеки України на період до 2025 року, затверджена Указом Президента України від 11 серпня 2021 року № 347/2021, норми якої визначають шляхи досягнення цілей і реалізації пріоритетів національних інтересів у сфері забезпечення економічної безпеки; однак все ще єдиним актом, де міститься нормативне закріплення поняття «економічна безпека», є наказ Міністерства економічного розвитку і торгівлі України № 1277 від 29 жовтня 2013 року «Про затвердження Методичних рекомендацій щодо розрахунку рівня економічної безпеки України», в якому зазначено, що економічною безпекою $€$ стан національної економіки, який дає змогу зберігати стійкість до внутрішніх та зовнішніх загроз, забезпечувати високу конкурентоспроможність у світовому економічному середовищі і характеризує здатність національної економіки до сталого та збалансованого зростання [4].

Економічна безпека держави $€$ одним із найважливіших складників національної безпеки, тому завжди виникає потреба в належній правовій регламентації інституціонального механізму ї захисту. Слід констатувати, що вітчизняне законодавство, зокрема вищезгаданий Закон № 2469VIII, є дещо не системним у даному питанні, тому що не визначає ні переліку суб'єктів забезпечення самої лише економічної безпеки, зважаючи на його орієнтованість на функціонування системи національної безпеки загалом, ні вичерпного переліку суб'єктів, діяльність яких спрямована на функціонування національної безпеки. Положення Стратегії економічної безпеки України на період до 2025 року покладають повноваження щодо іï реалізації лише на Кабінет
Міністрів України, Національний банк України, Національну комісію 3 цінних паперів та фондового ринку та Антимонопольний комітет України. На наше глибоке переконання, підхід законодавця $€$ дещо недопрацьованим, адже в зазначених нормативних документах він не згадує інші інституції, до компетенції яких прямо чи опосередковано він все ж відносить забезпечення вітчизняного економічно-безпекового середовища.

По-перше, йдеться про органи розвідки, правовий статус котрих має дещо специфічний характер, а діяльність не схожа на інші державні установи. Основним завданням розвідувального органу, в загальному розумінні, є збір важливої розвідувальної інформації, аналіз якої відкриває картину загроз у сфері національної економічної безпеки. Згадуючи про поняття «розвідка», ми завжди маємо на увазі воєнну розвідку, однак, як зазначає Ю.Є. Муравська, завдання економічної та воєнної розвідки різняться. Остання розвідує економічний потенціал конкретної країни чи організації та ї̈ вплив на обороноздатність країни. Крім того, воєнна розвідка є організацією, що спеціалізується на зборі інформації про інші країни 3 метою іï використання для політичних, економічних та воєнних цілей власної держави. У контексті цього визначення можна зробити висновок про особливість економічної розвідки як спеціальної організаційної структури, метою якої $€$ отримання інформації, а отже, і переваг тільки в економічній сфері [2].

Розвідувальними органами в Україні $€$ органи, уповноважені законом здійснювати розвідувальну діяльність 3 метою захисту національних інтересів України від зовнішніх загроз [6]. До таких законодавець відносить лише три: Службу зовнішньої розвідки України, розвідувальний орган Міністерства оборони України (Головне управління розвідки Міністерства оборони України) 
та розвідувальний орган центрального органу виконавчої влади, що реалізує державну політику у сфері охорони державного кордону.

Розвідувальний орган Міністерства оборони України (Головне управління розвідки Міністерства оборони України) є головним органом управління в системі воєнної розвідки та здійснює розвідувальну діяльність у воєнній, військово-технічній сфері, сферах оборони, військового будівництва і кібербезпеки, в межах повноважень координує діяльність суб'єктів воєнної розвідки і залучає в певних випадках окремих суб'єктів розвідувального співтовариства для виконання покладених на нього завдань та здійснення визначених законом функцій. Розвідувальний орган центрального органу виконавчої влади, що реалізує державну політику у сфері охорони державного кордону, тобто розвідувальний орган Державної прикордонної служби України, є розвідувальним органом, що здійснює розвідувальну діяльність у сфері безпеки державного кордону та охорони суверенних прав України в іï виключній (морській) економічній зоні [6]. Незважаючи на наявність у назві розвідувального органу прив'язки до Державної прикордонної служби, він є організаційно незалежним, зважаючи на те, що як організаційна структура, так і його гранична чисельність, визначаються Президентом України і не входять до структури та чисельності Державної прикордонної служби України. Правовою основою діяльності зазначених інституцій $€$ спеціальний закон від 17 вересня 2020 року № 912-IX «Про розвідку» (далі - Закон № 912IX). Закон № 912-IX передбачає, що керівництво всіма розвідувальними органами здійснює Президент України, а безпосереднє керівництво здійснюють їхні керівники, які призначаються на посаду і звільняються з посади Президентом України.

Щодо Служби зовнішньої розвідки України (далі - СЗРУ) слід зазначити, що окрім Закону № 912-IX, питання правового статусу СЗРУ також доповнюються положеннями спеціального закону України від 01 грудня 2005 року № 3160-IV «Про Службу зовнішньої розвідки України», які вказують, що СЗРУ є розвідувальним органом, що функціонує як окремий державний орган та не належить до системи органів виконавчої влади, здійснює свою діяльність під загальним керівництвом Президента України та демократичним цивільним контролем. СЗРУ здійснює розвідувальну діяльність у зовнішньополітичній, економічній, військово-технічній, науково-технічній, інформаційній, екологічній сферах, сфері кібербезпеки. Як розвідувальний орган України СЗРУ входить до складу сил безпеки, а як військове формування - до складу сил оборони сектору безпеки і оборони України. Керівництво Службою зовнішньої розвідки України здійснює Голова Служби зовнішньої розвідки України, який призначається на посаду і звільняється з посади Президентом України. Загальна чисельність служби затверджується в кількості 4350 співробітників, у тому числі до 4010 військовослужбовців, а в особливий період - у кількості згідно з Мобілізаційним планом Украіни [8].

Загалом, Закон № 912-IX визначає, що до повноважень розвідувальних органів для виконання своїх функцій та завдань належить: можливість організовувати та проводити розвідувальні заходи, тобто комплекс дій та рішень розвідувального органу із застосуванням методів, сил і засобів розвідки; здійснювати у визначеному законодавством порядку контрольоване пересування осіб та/або переміщення предметів через державний кордон України, опитування осіб, у тому числі з використанням технічних засобів реєстрації реакцій людини, спеціальне оброблення інформації 3 відкритих джерел, інформаційних систем, обліків, реєстрів, баз даних, 
а також інші повноваження, визначені законодавством. Форми, методи і засоби реалізації розвідувальними органами своїх повноважень визначаються законодавством, у тому числі актами розвідувальних органів, що містять таємну інформацію.

Усвідомлюючи той факт, що наукове дослідження будь-яких питань, пов'язаних із розвідувальною діяльністю, зважаючи на пї специфіку та наявність даних, що становлять державну таємницю, має деяку складність, та розуміючи, що доступ до наукових напрацювань $з$ даної тематики є обмеженим і недоступним для широкого загалу, з огляду на аналіз законодавчо закріплених функцій розвідувальних органів України та визначення поняття економічної безпеки держави пропонуємо надати таке загальне визначення компетенції розвідувальних органів у сфері економічної безпеки держави: «сукупність повноважень, прав та обов'язків розвідувальних органів держави, щзо полягають у здійсненні ними чи залученими суб'єктами розвідувального співтовариства комплексу diй та рішень із застосуванням методів, сил $i$ засобів розвідки, що спрямовані на отримання даних про наміри, плани $i$ дї іноземних держав, організацій та осіб чи про іхні потенційні можливості щодо реалізації таких намірів і планів, а також про прочеси, події, обставини, технології, знання, з метою збереження економічної стійкості mа протидії внутрішнім та зовнішнім економічним загрозам, забезпечення високої конкурентоспроможності у світовому економічному середовищі $i$ забезпечення сталого та збалансованого зростання вітчизняної економіки».

Слід зауважити, що практика покладення частини відповідальності за безпекову сферу національної економіки на органи розвідки держави не $€$ новелою для сучасних демократичних держав. Так, наявність загроз економіці Федеративної Республіки Німеччина визнається фундаментальною складовою частиною безпеки держави. У залежності від виду таких загроз формуються та впроваджуються механізми 3 протидії ї. Фокусуючи увагу на загальних рисах цієї системи, слід підкреслити, що державними органами, відповідальними за вироблення політики держави в галузі безпеки, є Федеральне міністерство оборони, а також Федеральне відомство з охорони Конституції та Федеральне відомство кримінальної поліції - суб'єкти, що входять до складу Федерального міністерства внутрішніх справ [1]. Не останню роль відіграє і Федеральна розвідувальна служба держави: відповідно до положень п. 2 ст. 1 Закону про Федеральну розвідувальну службу Німеччини (BND Law - BNDG), Федеральна розвідувальна служба збирає та оцінює інформацію, необхідну для отримання відомостей про зарубіжні країни, які мають велике значення для Федеративної Республіки Німеччини з точки зору зовнішньої політики й політики безпеки [7].

Фіскальні органи держави також мають надзвичайно важливе значення в забезпеченні фінансової безпеки як складника економічної, основними викликами та загрозами для якої $є$ : втрата доходів бюджету внаслідок поширених явищ «сірого» імпорту та контрабанди, схем ухилення від оподаткування, поширення явища легалізації (відмивання) доходів, одержаних злочинним шляхом, значний обсяг дефіциту державного бюджету тощо.

Важливо зазначити, що вітчизняні податкові/ фіскальні органи фактично весь період незалежності України перебувають у процесах реформування і трансформації, тобто змінюються їхні функції та завдання, а відповідно, й сукупність повноважень, прав та обов'язків, що є складниками їхньої компетенціі. Як результат різноманітних нововведень, наразі 
законодавство не містить поняття «фіскальний орган». Наявна до 18 грудня 2018 року як самостійний орган Державна фіскальна служба України була розподілена постановою Кабінету Міністрів України від 18 грудня 2018 року № 1200 на два самостійні органи: Державну податкову службу України (далі - ДПС) і Державну митну службу України (далі - Держмитслужба), повноваження яких $є$ аналогічними до повноважень ДФС, однак дещо більш спеціалізованими.

Державна митна служба України діє на підставі Положення, затвердженого постановою Кабінету Міністрів України від 6 березня 2019 р. № 227, та $€$ центральним органом виконавчої влади, основним завданням якого $€$ реалізація державної митної політики, а також державної політики у сфері боротьби з правопорушеннями під час застосування законодавства з питань митної справи, запобігання та протидія контрабанді, боротьба з порушеннями митних правил тощо. До повноважень Держмитслужби входить забезпечення та здійснення контролю за застосуванням митних режимів, цільовим використанням товарів, поміщених у відповідний митний режим, проведення спеціальних заходів щодо виявлення, попередження, припинення контрабанди наркотичних засобів, психотропних речовин, їх аналогів та прекурсорів, а також заходів з переміщення товарів під негласним контролем, участь у перевірках та інших заходах, що здійснюються державними органами, проведення адміністративного затримання осіб, які вчинили порушення митних правил; проведення документальних перевірок дотримання вимог законодавства 3 питань митної справи і зустрічних звірок, здійснення контролю за застосуванням тарифного та нетарифного регулювання зовнішньоекономічної діяльності під час пропуску товарів через митний кордон України, випуску їх у відповідний митний режим, а також після такого випуску тощо [13]. Окрім цього, вимоги законодавства про запобігання та протидію легалізації (відмиванню) доходів, одержаних злочинним шляхом (Закон України від 06.12.2019 р. № 361-IX), покладають на Держмитслужбу обов'язок щодо подання до спеціально уповноваженого органу інформації про виявлені факти незаконного переміщення через митний кордон України готівки, обігових грошово-кредитних документів, дорогоцінних металів, дорогоцінного каміння та виробів з них, а також культурних цінностей на суму, що дорівнює чи перевищує 400 тисяч гривень [9]. Положення Закону України № 330-XIV «Про захист національного товаровиробника від демпінгового імпорту» від 22.12.1998 р. уповноважують Службу здійснювати антидемпінгове розслідування в Україні, тобто розслідування наявності факту ввезення на митну територію країни імпорту товару за цінами, нижчими від порівняної ціни на подібний товар у країні експорту, що заподіює шкоду національному товаровиробнику подібного товару [10]. Відповідно до положень Закону України № 332-XIV «Про застосування спеціальних заходів щодо імпорту в Україну» від 22.12.1998 р., до предмету відання Держмитслужби входить і здійснення заходів щодо нагляду за обсягом імпорту в Україну та у разі, якщо зростання обсягу імпорту в Україну відбувається в таких розмірах та (або) у такі строки або на таких умовах, що заподіюється або існує загроза заподіяння значної шкоди, тобто виникають підстави застосування передбачених цим законом спеціальних заходів, на Службу покладається обов'язок інформування про це Міністерство економіки України [11]. Згідно з положеннями Закону України № 331-XIV «Про захист національного товаровиробника від субсидованого імпорту» від 22.12.1998 р., Державна митна служба є одним 
з органів, уповноважених зазначеним Законом на проведення й антисубсидиційне розслідування в Україні, тобто розслідування факту надання нелегітимної фінансової або іншої підтримки державними органами виробництва, переробки, продажу, транспортування, експорту, споживання подібного товару, в результаті якої суб’єкт господарсько-правових відносин країни експорту одержує пільги (прибутки) [12]. Таким чином, компетенція Держмитслужби в секторі економічної безпеки держави полягає у здійсненні контрольно-наглядових та правоохоронних повноважень, реалізація яких забезпечує надходження до дохідної частини вітчизняного бюджету, запобігання процесу контрабанди товарів, уникнення нераціональної структури імпорту й експорту та слугує своєрідним каталізатором для вільного руху товарів і капіталів, створюючи при цьому сприятливі умови для інтеграції вітчизняної економіки в міжнародний поділ праці.

Чільне місце серед суб'єктів, що реалізують фіскальну політику держави, займає й Державна податкова служба України (далі - ДПС), правовий статус якої регламентований положенням, затвердженим постановою Кабінету Міністрів України № 227 від 6 березня 2019 р. Державна податкова служба України є центральним органом виконавчої влади, діяльність якого спрямовується і координується Кабінетом Міністрів України через Міністра фінансів i який реалізує державну податкову політику, державну політику з адміністрування єдиного внеску на загальнообов'язкове державне соціальне страхування. Завданнями ДПС $€$ реалізація державної податкової політики, здійснення контролю за надходженням до бюджетів та державних цільових фондів податків, зборів, платежів, державної політики у сфері контролю за виробництвом та обігом спирту, алкогольних напоїв, тютюнових виробів тощо, державної політики 3 адміністрування єдиного внеску, контролю за наявністю ліцензій на провадження видів господарської діяльності, що підлягають ліцензуванню відповідно до закону. Для виконання поставлених завдань ДПС здійснює реєстрацію та веде облік платників податків, платників єдиного внеску, об'єктів оподаткування та об'єктів, пов'язаних 3 оподаткуванням, забезпечує достовірність та повноту ведення обліку платників податків (платників єдиного внеску), об'єктів оподаткування й об'єктів, пов'язаних 3 оподаткуванням, забезпечує формування та ведення Державного реєстру фізичних осіб - платників податків, інших реєстрів, банків і баз даних, забезпечує ведення обліку податків, зборів, платежів, здійснює адміністрування податків, зборів, платежів, єдиного внеску, в тому числі проводить відповідно до законодавства перевірки та звірки платників податків (платників єдиного внеску), контролює своєчасність подання платниками податків передбаченої законом звітності, своєчасність, достовірність, повноту нарахування та сплати податків, зборів, платежів, єдиного внеску, застосовує до платників податків (платників єдиного внеску) передбачені законом фінансові (штрафні) санкціï (штрафи) за порушення вимог податкового законодавства чи законодавства 3 інших питань, контроль за дотриманням якого покладено на ДПС [13]. Тому можна зробити висновок, що компетенція Державної податкової служби України в секторі економічної безпеки полягає у здійсненні контролю як за належним надходженням податків та зборів до відповідних бюджетів, так і за правильністю нарахування та своєчасністю сплати податків їх платниками, виконанням вимог податкового законодавства 3 метою протидії схемам ухилення від оподаткування та, як наслідок, втратам доходів бюджету 
і гарантування стабільності української економіки.

Ще одним органом, головною метою якого є забезпечення економічного добробуту держави, $є$ Національне агентство України з питань виявлення, розшуку та управління активами, одержаними від корупційних та інших злочинів (далі - AРMA, Агентство). APMA $€$ центральним органом виконавчої влади зі спеціальним статусом, що забезпечує формування та реалізацію державної політики у сфері виявлення, розшуку та управління активами, на які може бути накладено або вже накладено арешт у кримінальному провадженні чи у справі про визнання необгрунтованими активів та їх стягнення в дохід держави, або які конфісковано чи стягнено в дохід держави внаслідок визнання ї необгрунтованими. Правову основу діяльності Агентства становлять Конституція України, міжнародні договори, згоду на обов'язковість яких надано Верховною Радою України, а також спеціальний закон № 772-VIII «Про Національне агентство України 3 питань виявлення, розшуку та управління активами, одержаними від корупційних та інших злочинів» від 10.11.2015 р., Кримінальний процесуальний кодекс України та інші закони. Агентство $€$ підзвітним Верховній Раді України, а підконтрольним та відповідальним перед Кабінетом Міністрів України, де питання діяльності Агентства представляє його Голова. Організаційно Національне агентство складається 3 центрального апарату і 6-ти територіальних управлінь у Києві, Львові, Харкові, Вінниці, Одесі та Дніпрі. Основними функціями АРMА є: проведення аналізу статистичних даних, результатів досліджень та іншої інформації про виявлення, розшук та управління активами; підготовка пропозицій щодо формування та реалізації державної політики у сфері виявлення, розшуку та управління активами, здійснення заходів з вияв- лення, розшуку, проведення оцінки активів за зверненням слідчого, детектива, прокурора, суду (слідчого судді), організація здійснення заходів, пов'язаних із проведенням оцінки, веденням обліку та управлінням активами, формування та ведення Єдиного державного реєстру активів, на які накладено арешт у кримінальному провадженні, здійснення співробітництва з органами іноземних держав, до компетенції яких належать питання щодо виявлення, розшуку та управління активами, іншими компетентними органами іноземних держав, відповідними міжнародними організаціями тощо [15]. Таким чином, зміст компетенції АРMA в секторі економічної безпеки держави становить діяльність щодо запобігання вчиненню нових корупційних правопорушень шляхом здійснення заходів щодо виявлення, розшуку, арешту, конфіскації незаконно одержаних благ (активів) та їх управління.

Ще однією установою, яку доцільно було би вказати, є Бюро економічної безпеки України (далі - Бюро), яке де-юре вже існує серед центральних органів виконавчої влади, однак де-факто повноцінно ще не функціонує. Новостворений орган має на меті замінити підрозділи податкової міліції у складі ДФС та економічні підрозділи СБУ і Національної поліції та стати єдиним центральним органом виконавчої влади, на який покладаються завдання щодо забезпечення економічної безпеки держави шляхом запобігання, виявлення, припинення, розслідування кримінальних правопорушень, що посягають на функціонування економіки держави; виявлення зон ризиків у сфері економіки шляхом аналізу структурованих і неструктурованих даних; оцінювання ризиків і загроз економічній безпеці держави, напрацювання способів їх мінімізації та усунення тощо. Правову основу діяльності Бюро економічної безпеки України становить Закон України № 1150-IX «Про Бюро економічної 
безпеки України» від 28.01.2021 р. Бюро здійснює свої повноваження через центральний апарат і територіальні управління, які утворюються, реорганізовуються і ліквідовуються Кабінетом Міністрів України. Керівництво Бюро економічної безпеки України здійснює Директор, який у свою чергу затверджує структуру, штатний розпис, положення про структурні підрозділи центрального апарату і територіальних управлінь і посадові інструкції працівників. Для виконання поставлених завдань Бюро здійснюватиме оперативно-розшукову діяльність і досудове розслідування в межах передбаченої законом підслідності, інформаційно-пошукову та аналітично-інформаційну роботу з метою виявлення та усунення причин і умов, що сприяють учиненню кримінальних правопорушень, віднесених до підслідності Бюро економічної безпеки України, здійснюватиме розшук осіб, які переховуються від органів досудового розслідування, слідчого судді, суду або ухиляються від відбування кримінального покарання за вчинення кримінальних правопорушень, буде збирати та аналізувати інформацію щодо кримінальних правопорушень, віднесених законом до його підслідності та ін. [14]. Отже, компетенція Бюро у сфері гарантування вітчизняного економічно-безпекового середовища полягає у здійсненні ним діяльності оперативно-розшукового та аналітичного спрямування 3 метою протидії правопорушенням, що посягають на функціонування економіки держави.

Висновки. Таким чином, сфера економічної безпеки України є складною системою з досить розгалуженою мережею суб'єктів іï забезпечення, серед яких розвідувальні та фіскальні органи, які відповідно до власного функціонального призначення й $\mathrm{y}$ межах компетенціі відіграють велику роль у протидії загрозам економічній стійкості, схемам ухилення від оподаткування, контрабанді, втратам доходів бюджету та забезпечу- ють стале і збалансоване зростання вітчизняної економіки, іï конкурентоспроможності, а також, що досить важливо, - захист вітчизняного товаровиробника. Вказане повинно змусити законодавця та науковців дещо переглянути своє бачення ролі статусу проаналізованих органів у формуванні безпекового економічного середовища для подальшої оптимізації та вжиття відповідних заходів удосконалення правового врегулювання аналізованої сфери відносин у довгостроковій перспективі.

Виклики сучасного світу змушують держави демонструвати послідовність та чітку політику захисту власного економічного сектору від загроз як усередині, так $i$ ззовні, наділяючи різні вітчизняні інститути відповідними повноваженнями. Наразі український законодавець не виробив єдиного системного підходу щзодо розуміння того, які державні органи складають систему суб'єктів, на яких лежить відповідальність за гарантування економічної безпеки нашої держави, внаслідок чого розвідувальні та фіскальні органи України хоча й наділені окремими повноваженнями щодо прогнозування, виявлення та ліквідації економічних загроз, однак не розглядаються як одні із ключових складників системи. У статmі досліджено норми чинного законодавства України стосовно питання визначення правового статусу та компетениіі окремих розвідувальних та фіскальних органів України в секторі економічної безпеки держави з точки зору ролі їхніх повноважень у формуванні вітчизняного економічного безпекового середовища; проаналізовано положення вітчизняних правових актів стосовно нормативного закріплення поняття «економічна безпека». Зважаючи на дещо обмежений доступ до підзаконних актів, що деталізують питання організаціі та 
функціонування діяльності окремих розвідувальних органів, а також до наукових праць, присвячених даному питанню, автором надано загальне визначення компетенціі розвідувальних органів у сфері економінноі безпеки держави. Також у статті підкреслено необхідність переосмислення ролі та статусу розвідувальних та фіскальних органів України не тільки як суб'єктів забезпечення вітчизняного економічного безпекового середовища, а $і$ як суб'єктів формування сектору національної безпеки загалом. Констатовано дуалізм законодавия в підході щзодо наділення повноваженнями окремих органів стосовно формування економічної безпеки держави та визначення відповідальних за ї забезпечення інституиій у довгостроковій перспективі. Визначено, які центральні органи виконавчої влади актуально відносити до категорії «фіскальні органи», досліджено їхій правовий статут, а також на підставі норм чинного законодавства дана характеристика компетенції кожного органу з точки зору їх значення для гарантування економічного безпекового середовища України. Доведено, що оптимізація механізму гарантування економічної безпеки держави є неефективною без удосконаленням правового регламентування діяльності органів розвідки та фіскальних органів.

Ключові слова: економічна безпека держави, розвідувальні органи, фіскальні органи, правовий статус, компетенція, протидія економічним загрозам.

Kolisnyk A. Legal status, competence of fiscal and intelligence bodies in the sector of economic security of the state

The challenges of the modern world force states to demonstrate a consistency and a clear policy of protecting their own economic sector from both internally and externally threats, endowing various domestic institutions with appropriate powers. Currently, the Ukrainian legislator has not developed a single systematic approach of understanding which government agencies belong to the system of entities, which are responsible for the economic security ensuring of our state. As a result, empowered with separate powers of forecasting, detection and elimination of economic threats intelligence and fiscal authorities of Ukraine are not considered as the key components of the system. The article examines the current legislation of Ukraine concerning the legal status and competence of certain intelligence and fiscal bodies of Ukraine in the economic security sector in terms of the role of their powers concerning the domestic economic security environment shaping; analyzes the provisions of domestic legal acts concerning normative fixing of the concept of «economic security». Considering the limited access to the secondary legislation acts, which regulate the individual intelligence agencies organization and functioning, as well as to scientific papers on this issue, the author provides a general definition of the "competence of intelligence agencies in the field of economic security». Also, the article emphasizes the need to rethink the role and status of intelligence and fiscal authorities of Ukraine not only as the actors of ensuring the domestic economic security environment, but also as actors of national security sector formation in general. The article states the fact of the legislator dualism concerning the approach of empowering certain bodies in the sphere of the economic security formation of the state and determining the responsible institutions for a long-term economic security provision. The author determined which central executive bodies belong to the "fiscal bodies» category, described their legal status 
and competence considering their importance for ensuring the economic security environment of Ukraine. It is proved that the optimization of the guaranteeing mechanism of the economic security of the state is ineffective without improving the legal regulation of the intelligence and fiscal authorities activities.

Key words: economic security of the state, intelligence bodies, fiscal bodies, legal status, competence, counteraction to economic threats.

\section{Література}

1. Господарик Ю.П., Пашковская М.В. Международная экономическая безопасность. Москва: Университет «Синергия», 2016. 416 c.

2. Муравська Ю.Є. Економічна та воєнна розвідка: від теорії до практики. Економічна безпека та фінансові розслідування: концепти, прагматика, інструментарій забезпечення : колективна монографія. Тернопіль : Економічна думка, 2019. 395 c. URL: http: / / ir.nusta.edu.ua / ispui / bitstream / doc/4085/1/2907_IR.pdf (даma звернення: 13.09.2021).

3. Про нациінальну безпеку України : Закон України від 21.06.2018 р. № 2469VIII. URL: https:/ / zakon.rada.gov.ua/ laws/show/2469-19\#Text (Jama звернення: 06.09.2021).

4. Про затвердження Методичних рекомендацій щодо розрахунку рівня економічної безпеки України : наказ Міністерства економічного розвитку $i$ торгівлі України від 29.10.2013 р. № 1277. URL: https: / / zakon.rada.gov.ua/rada/ show/v1277731-13\#Text (даma звернення: 21.09.2021).

5. Про рішення Ради національної безпеки $i$ оборони України від 11 серпня 2021 року «Про Стратегію економічної безпеки України на період до 2025 року» : Указ Президента Украінни від 11.08.2021 p. № $347 / 2021$. URL: https: / / zakon.rada.gov.ua/laws / show/347/2021\#Text (дата звернення: 08.09.2021)

6. Про розвідку : Закон України від 17.09.2020 p. № 912-IX. URL: https: / / zakon.rada.gov.ua / laws / show/912-20\#Text (дата звернення: 10.09.2021)
7. Gesetz bber den Bundesnachrichtendienst (BND-Gesetz - BNDG): BND-Gesetz vom 20. Dezember 1990. URL: http: / / www.gesetze-im-internet.de (Jama звернення:12.09.2021).

8. Про Службу зовнішньої розвідки України : Закон України від 01.12.2005 p. № 3160-IV. URL: https: / / zakon.rada.gov.ua/ laws/show/3160-15\#Text (Jаma звернення: 10.09.2021).

9. Про запобігання та протидію легалізаиіі (відмиванню) доходів, одержаних злочинним шляхом, фінансуванню тероризму та фінансуванню розповсюдження зброї масового знищення : Закон України віО 06.12.2019 р. № 361-IX. URL: https: / / zakon.rada.gov.ua / laws / show/361-20\#Text (дата звернення: 22.09.2021).

10. Про захист національного товаровиробника від демпінгового імпорту : Закон України від 22.12.1998 р. № 330XIV. URL: https://zakon.rada.gov.ua/ laws/show/330-14\#Text (дата звернення: 22.09.2021).

11. Про застосування спецуіальних заходів щодо імпорту в Україну : Закон України від 22.12.1998 p. №332-XIV. URL: https: / / zakon.rada.gov.ua / laws / show/332-14\#Text (дата звернення: 21.09.2021).

12. Про захист національного товаровиробника від субсидованого імпорту : Закон України від 22.12.1998 р. №331-XIV. URL: https: / / zakon.rada.gov.ua/laws / show/331-14\#Text (дата звернення: 21.09.2021).

13. Про затвердження положень про Державну податкову службу України та Державну митну службу України: постанова Кабінету Міністрів України від 06.03.2019 р. № 227. URL: https: / / zakon.rada.gov.ua/laws / show/227-2019-\%D0\% BF\#Text (Jama звернення: 23.09.2021).

14. Про Бюро економічної безпеки України: Закон України від 28.01.2021 р. № 1150IX. URL: https: / / zakon.rada.gov.ua/laws / show/1150-20\#Text (дата звернення: 23.09.2021)

15. Про Національне агентство України з питань виявлення, розшуку та управління активами, одержаними від корупиійних та інших злочинів : Закон України від 10.11.2015 р. № 772-VIII. URL: https: / / zakon.rada.gov.ua / laws / show/772-19\#Text (дата звернення: 22.09.2021). 